\title{
KESENJANGAN KOMUNIKASI ORANG TUA DAN ANAK DALAM MENGHADAPI PEMBELAJARAN ONLINE DI MASA PANDEMI COVID-19
}

\author{
Intan Mustafa ${ }^{1}$ | Lodowik Nikodemus.Kedoh ${ }^{1}$ | Maria Yosephine Desire ${ }^{1}$
}

1Program Studi IImu Komunikasi,

Fakultas IImu - IImu Sosial, Universitas Nusa Nipa Maumere Jalan Kesehatan 3, Maumere 86111 Nusa Tenggara Timur.

\section{Corresponding:}

Intan Mustafa

intanmustafa15@gmail.com
Abstract: Learn from home has become a new trend today. This study examines how the communication gap that occurs between parents and children in the online learning process during the covid-19 pandemic. The method used is a case study, with data collection techniques through observation, interviews and documentation review. The results of the study indicate that quite a number of problems have arisen against this government policy, and one of them is the communication problem of parents in their unpreparedness having a dual role in their upbringing as teachers, motivators and facilitators for their children. In addition, other problems such as supporting facilities, social environment and children's mentality are other obstacles that contribute to creating a communication gap between parents and children. Through this research, it is hoped that the communication relationship between parents and children should be a priority, so that the current pandemic situation does not necessarily reduce children's interest in learning and academic potential.

Keywords: Communication Gap, Online Learning, Covid-19 Pandemic

\begin{abstract}
Abstrak: Belajar dari rumah telah menjadi trend baru saat ini. Penelitian ini mengkaji tentang kesenjangan komunikasi antara orang tua dan anak dalam proses pembelajaran online di masa pandemi covid-19. Metode yang digunakan ialah studi kasus, dengan teknik pengumpulan data melalui observasi, wawancara dan telaah dokumentasi. Hasil penelitian menunjukkan bahwa cukup banyak persoalan yang muncul terhadap kebijakan pemerintah ini, dan salah satunya yakni problem komunikasi orang tua dalam ketidaksiapannya berperan ganda dalam pengasuhannya sebagai pengajar, motivator dan fasilitator bagi anak-anaknya. Selain itu, persoalan lain seperti fasilitas penunjang, lingkungan sosial serta mental anak menjadi kendala lain yang turut berkontribusi dalam menciptakan kesenjangan komunikasi orang tua dan anak. Melalui penelitian ini diharapkan agar relasi komunikasi orang tua kepada anak mesti menjadi prioritas, sehingga situasi pandemi seperti saat ini tidak serta merta menurunkan minat belajar dan potensi akademik anak.
\end{abstract}

Kata Kunci: Kesenjangan Komunikasi, Pembelajaran online, Pandemi Covid-19 


\section{1 | PENDAHULUAN}

Pandemi virus corona saat ini membawa dampak yang besar dan cepat. Dalam kurun waktu singkat, virus ini secara drastis mengubah tatanan hidup milyaran penduduk dunia yang dipaksa untuk 'tinggal di rumah', mengisolasi diri', dan bekerja serta belajar dari rumah. Kondisi inipun menimbulkan persoalan serius pada sistem pendidikan secara global. Hampir 200 negara menutup sekolah dengan lebih dari $90 \%$ pelajar ini mulai dari tahun-tahun awal hingga pendidikan tinggi menghadapi semacam gangguan pada pendidikan mereka (Garbe et al., 2020). Permasalahan di beberapa negara berkaitan tentang pembelajaran online juga terjadi. Faktor yang mempengaruhi terjadinya kesenjangan dan permasalahan dalam sekolah online antara lain gender, jangkauan tempat tinggal (Parczewska, 2021), keterampilan siswa, dan fasilitas di rumah (Bhamani et al., 2020).

Kondisi yang demikian menjadi tantangan bagi proses pembelajaran baik bagi siswa maupun orang tua yang tengah mendampingi. Keterbatasan fasilitas dan keterampilan menjadi faktor utama yang terjadi di Indonesia. Oleh karenanya, pemerintah melakukan upaya yang optimal dalam mengurangi angka kematian dan tingkat penyebaran covid 19. Upaya untuk menekan penyebaran COVID-19 mendorong kebijakan pemerintah melakukan penutupan sekolah yang tidak terjadwal di seluruh dunia (Onyema et al., 2020). Trend baru di masa pandemi dengan beraktivitas dari rumah, ternyata membawa dampak dan perubahan bagi hampir semua populasi manusia di dunia. Bagaimana tidak, melemahnya kontak sosial ini, justru menimbulkan kecemasan, dan meningkatkan stress karena gangguna pada gaya hidup normal yang semestinya (Martens et al., 2021). Di Indoenesia dampak pandemi covid 19 di bidang pendidikan juga sangat beragam. Dampak tersebut meliputi perubahan kebijakan sistem pembelajaran sekolah (Pujilestari, 2020), perubahan metode pembelajaran (Samudera, 2020), kebingungan siswa dalam beradaptasi (Jauhari et al., 2020), menghilangkan matapelajaran praktikum (Loviana \& Baskara, 2020).

Di Indonesia sendiri kebijakan belajar dari rumah menjadi langkah strategis agar hak anak bangsa dalam memperoleh pendidikan dapat terus berjalan. Konsep belajar dari rumah sendiri menekankan pada sistem pembelajaran virtual, yang mana sistem akademik berproses menggunakan media digital. Pada poin ini, orang tua akhirnya dituntut berperan ganda dalam menjalankan pengasuhannya terhadap anak, baik itu sebagai ayah dan ibu serta pengganti guru dirumah, karena biar bagaimanapun keluarga merupakan istitusi terpenting dalam proses belajar anak (Uzun et al., 2021).

Pandemic covid 19 di dunia membawa dampak yang besar bagi seluruh level kehidupan termasuk jika dikategorikan dalam usia. Diperkirakan bahwa individu yang paling terpengaruh oleh situasi ini adalah anak-anak, dan oleh karena itu penting untuk memeriksa kembali faktor-faktor epidemi yang dialami saat ini yang mempengaruhi hubungan keluarga-anak. Banyak penelitian yang telah dilakukan kepada para orang tua yang menunjukkan reaksi beragam atas kebijakan belajar dari rumah ini dan untuk mengkaji bagaimana peran orang tua selama masa pandemic ini, Dukungan orang tua telah menunjukkan kontribusi yang signifikan terhadap keberhasilan peserta didik dalam lingkungan pembelajaran virtual dan tidak sedikit yang memberikan ulasan terkait kesulitan yang ditemui orang tua mulai dari membagi peran dan tanggung jawab, memotivasi anak, aksesibilitas, dan hasil belajar anak (Garbe et al., 2020).

Fenomena yang muncul saat anak-anak tidak pergi ke sekolah adalah kegiatan mereka didominasi dengan kegiatan di dalam rumah. Bahkan untuk keluar rumah juga menjadi ancaman kesehetan tersendiri bagi anak. Sehingga orang tua memiliki tugas lebih dalam menjaga dan mendidik anak. Permaslahan yang timbul saat anak lebih banyak di rumah adalah anak-anak lebih banyak menggunakan gadget (gawai) dari pada berinteraksi di dengan anggota keluarga. Dalam Wardani \& Ayriza (2020), menyatakan bahwa kesulitan komunikasi orang tua dengan anak di masa 
pandemic dijembatani oleh pengalihan kegiatan nyata ke dunia maya. Dalam artian bahwa anak diperbolehkan menggunakan gawai. Gawai dijadikan sebagai solusi untuk mengalihkan kebosanan sehingga pada akhirnya menjadi kebiasaan anak dalam penggunaan gawai. Dalam Setiyaningsih et al., (2021) menyebutkan bahwa terpaan media baru atau dalam hal ini penggunaan gawai secara berlebihan menyebabkan terjadinya kesalahpahaman komunikasi antara orang tua dan anak.

Hal ini juga terjadi karena terdapat dukungan bahwa dalam pembelajaran anak juga diwajibakan menggunakan gawai dalam penyelesaian tugasnya. Seluruh jenjang pendidikan menggunakan gawai untuk mendukung metode pembelajaran secara daring (dalam jaringan) mulai dari paud (Suhendro, 2020), taman kanak-kanak (Anhusadar, 2020; Sudrajat et al., 2020; Lestari et al., 2021); sekolah dasar (Astini, 2020; Putria et al., 2020); sekolah menengah pertama (Fauzy \& Nurfauziah, 2021; Rochman et al., 2020), dan sekolah tingat atas (Cahyani et al., 2020; Megawanti, 2020). Pasalnya, anak di rumah menggunakan gawai untuk dijadikan sebagai media pencarian tugas dan kebutuhan hivuran lainya. Dengan kata lain, penggunaan gawai selainmenjadi fungsi pendidikan dan informasi juga didominasi fungsi hiburan (Setiyaningsih et al., 2020). Dan pada posisi ini para orang tua mengalami kewalahan dalam mengontrol kebasaan anak dalam penggunaan gawai. Sehingga komunikasi keluarga antara orang tua dengan anak mengalami distorsi (Dzaljad, 2020; Triono \& Setiyaningsih, 2017).

Kesulitan ataupun persoalan yang dihadapi oleh orang tua sejatinya menjadi suatu hal yang memprihatinkan, hal ini karena banyak orang tua yang justru selama ini menempatkan jarak dalam membangun relasi dengan anak, dan komunikasi menjadi salah satu persoalan yang kerap dijumpai pada sebagain hubungan orang tua dan anak, alhasil orang tua akhirnya mempercayakan sepenuhnya urusan Pendidikan ke tangan para guru dengan anggapan bahwa tempat belajar anak adalah disekolah. Tujuan penelitian ini adalah untuk mengetahui serta memaparkan seperti apa kesenjangan komunikasi yang terjadi antara orang tua dan anak selama menghadapi pembelajaran online dimasa pandemic Covid - 19.

Jika dalam Wardani \& Ayriza (2020), menyatakan bahwa hal utama dalam mengatasi permasalah sekolah daring adalah dengan mengenali kendala terstruktur dari anak yang dilakukan oleh orang tuanya. Namun sebelumnya terdapat temuan bahwa justru keterlibatan orang tua dalam mengendalikan penggunaan gawai mempengaruhi hasil dari pembelajaran online (Irma et al., 2019; Setiyaningsih \& Jatmikowati, 2019). Maka dalam penelitian ini mempertajam bahwa mengetahui dan menyelesaikan kesenjangan komunikasi menjadi faktor yang juga menentukan keberhasilan dalam pembelajaran online dengan komunikasi dua arah antara anak dan orang tua.

\section{2 | METODE PENELITIAN}

Penelitian ini bersifat deskriptif kualitatif, dengan menggambarkan atau melukiskan keadaan suatu obyek atau peristiwa (Kartini, 1996). Dalam penelitian ini, menggambarkan situasi atau keadaan yang terjadi terkait kesenjangan komunikasi antara orang tua anak selama pembelajaran online di masa pandemic covid 19. Sumber data pada penelitian ini meliputi data primer; diperoleh dari hasil wawancara peneliti terhadap informan. Dalam penelitian ini, peneliti mengumpulkan data primer dengan melakukan wawancara kepada para informan yang diambil melalui teknik snowball sampling, dengan kriteria: orang tua yang memiliki anak usia .Sekolah Dasar, anak usia Sekolah Dasar. Sedangkan data sekunder; diperoleh dari studi pustaka, dokumentasi dan juga observasi terkait situasi pembelajaran online pada anak usia sekolah dasar.

Teknik pengumpulan data melalui interview/wawancara; jenis interview yang digunakan dalam peneliltian ini adalah dept interview, yakni wawancara tak berstruktur. Dalam melakukan interview yang dimaksud peneliti sebagai pewawancara hanya membuat garis besar terkait hal-hal yang akan diungkap melalui pertanyaan. Dan selanjutnya akan berkembang dengn sendirinya dilapangan. Observasi; digunakan peneliti untuk memperoleh pemahaman mengenai komunikasi 
orang tua dan anak dalam pembelajaran online di masa pandemi.

Studi Dokumentasi; untuk mengambil data-data pendukung untuk melengkapi penelitian yang berkaitan dengan masalah yang diteliti, seperti keadaan dan monografi, dapat melengkapi data yang diperlukan dalam penelitian. Dalam penelitian ini, komponen yang digunakan untuk menganalisis data, yakni pertama pengumpulan data yang diperoleh melalui Iwawancara, observasi dan dokumentasi, selanjutnya data tersebut di reduksi yaitu menggolongkan dan mengeneralisir data sesuai kebutuhan penelitian, tahap selanjutnya adalah verifikasi, dengan menarik kesimpulan (Sugiyono, 2017).

\section{3 | HASIL DAN PEMBAHASAN}

Komunikasi orang tua menjadi bagian vital dalam proses pembentukan sikap dan prilaku anak yang akan berpengaruh pada perkembangan mental dan kepribadian anak dan disinilah unsur pendidik terhadap anak di bentuk. Apalagi situasi pandemi saat ini. Orang tua harusnya mampu memainkan peran ganda, yakni tidak hanya bertindak sebagai ayah dan ibu yang melahirkan, mengasuh dan memenuhi kebutuhan finansial sang anak saja, namu juga sebagai pengajar yang membantu tugas guru dalam menerangkan, mengarahkan dan memberikan pengetahuan terkait ilmu pengetahuan. Dan salah satu cara adalah dengan berkomunikasi untuk menanamkan nilai - nilai tersebut diatas.

Dari hasil penelitian ini, ditemukan bahwa cukup banyak persoalan kesenjangan komunikasi orang tua kepada anak terlihat selama masa pandemic ini, hal ini karena durasi kebersamaan orang tua anak anak selama dirumah bertambah dengan adanya pemberlakuan belajar dan bekerja dari rumah. Pemenuhan kebutuhan komunikasi dalam menjalankan peran sebagai orang tua yang tidak hanya sekedar memenuhi kebutuhan fisiologis sang anak, namun lebih dari itu orang tua juga pengajar serta pendidik dirasakan mengalami kendala yang cukup berarti. Dari pengumpulan data yang dilakukan, terdapat beberapa persoalan kesenjangan komunikasi orang tua dan anak.

\section{Komunikasi Orang Tua sebagai Pendidik}

Pendekatan emosional dan motivasi menjadi dua unsur penting dalam memerankan tugas sebagai pendidik bagi anak - anak selama pembelajaran online dirumah. Sejauh ini, justru dua hal ini yang menjadi kendala bagi sebagian orang tua. Urusan sebagai pendidik, sudah terlanjur disematkan kepada peran guru disekolah, sehingga ada sebagian orang tua yang nyaris tidak pernah lagi mengulangi setiap apa yang telah menjadi aktivitas sang anak disekolah. Secara emosional, komunikasi yang dibangun justru lebih kepada reward dan punishment terhadap aktifitas akademik sang anak, namun jarang terlihat bagaiamana motivasi dan pemberian waktu khusus untuk menemani dan mendamping anak belajar dirumah. Mekanisme komunikasi yang harusnya dibangun orang tua sebagai pendidik semestinya mengacu kepada metode-metode pembelajaran disekolah seperti metode bermain, demonstrasi dan tanya jawab namun dengan pendekatan emosional anatara orang tua dan anak, Kendala lain yang ditemui dalam penelitian ini ialah minimnya komunikasi yang terjalin antara orang tua dan anak, dipicu oleh tingkat pendidikan orang tua. Efektivitas komunikasi akan mampu terjalin dengan baik, jika orang tua mampu mengimbangi materi pembelajaran anak karena pengetahuan yang telah diperoleh sebelumnya. Karena intensitas komunikasi yang dibangun secara interpersonal antara orang tua dan anak, tidak hanya berpengaruh pada konten atau isi komunikasi tapi dapat meningkatkan hubungan emosial keduanya (Liliweri, 2017).

Komunikasi orang tua dan anak yang efektif adalah menggunakan komunikasi dua arah. 
Permaslahan yang muncul adalah jika orang tua menerapkan komunikasi satu arah dalam mengarahkan anaknya saat pembelajaran. Hal ini menjadi beban bagi anak dalam pengerjaan tugas dan menjalankan aktifitas daring sekolah bagi anak. Oleh karenanya model komunikasi dua arah sangat disarankan dalam penelitian ini. Orang tua hanya menjadi komunikator namun juga sekaligus menjadi komunikan dalam praktiknya. Begitu juga sebaliknya, anak dapat diposisikan menjadi komunikator dan sekaligus komunikan. Hal ini memberikan aspek kemandirian dan tanggung jawab bagi anak.

\section{Komunikasi Orang Tua sebagai Pembimbing}

Kesenjangan komunikasi yang kedua ini, menuntut peran orang tua dalam proses pendampngan anak selama pembelajaran online dirumah. Minimnya waktu khusus yang disiapkan para orang tua menjadi kendala yang sering dihadapi para orang tua. Kesibukkan pekerjaan, menjadi alas an yang melatarbelakangi orang tua jarang mendampingi anak selama belajar. Dalam Kurniati et al., (2020) orang tua memiliki peran khusus yakni: menjaga dan memastikan anak untuk menerapkan hidup bersih dan sehat, mendampingi anak dalam mengerjakan tugas sekolah, melakukan kegiatan bersama selama di rumah, menciptakan lingkungan yang nyaman untuk anak, menjalin komunikasi yang intens dengan anak, bermain bersama anak, menjadi role model bagi anak, memberikan pengawasan pada anggota keluarga, menafkahi dan memenuhi kebutuhan keluarga, dan membimbing dan memotivasi anak, memberikan edukasi, memelihara nilai keagamaan, melakukan variasi dan inovasi kegiatan di rumah. Diperlukan panduan bagi orang tua dalam membantu mendampingi kegiatan anak yang berbasis pada kebutuhan anak selama pandemi dan selama belajar dari rumah.

Kurangnya pemahaman fitur pembelajaran online, menjadikan sebagian orang tua memiliki keengganan dalam mendampingi anak belajar. Persoalannya selanjutnay adalah, para orang tua tersebut juga kurang memiliki motivasi untuk mencaritahun seperti apa dan bagaimana fitur belajar online tersebut, sehingga komunikasi yang dibangun bersama anak akhirnya terabaikan. Orang tua biasanya lebih focus kepada hasil belajar anak, dari pada proses yang dilalui. sehingga terkadang orang tua tidak memaksimalkan komunikasi sebagai pembimbing belajar dengan baik. Disini, anak akan dibiarkan sendiri mengakses bahkan mengerjakan tugas dari media HP, dan hasilnya kontrol terhadap aktivitas belajar online terasa berkurang. Dalam Fahmi (2020), pembelajaran yang efektif menggunakan komunikasi singkronus dan asingkronus. Dan hal ini sangat membantu serta memudahkan orang tua dalam melakukan pengawasan anak di rumah saat belajar.

\section{Komunikasi orang tua sebagai motivator}

Pandemi covid 19 selama kurun waktu satu tahun ini, turut berpengaruh pada psikologis anak. Penyesuaian dari aktivitas berkumpul dan bermain di sekolah harus dihadapi dengan belajar mandiri dari rumah. Menjaga metal dan emosi anak menjadi tanggung jawab orang tua melalui pemberian motivasi terhadap setiap aktivitas dan perilaku anak (Trevarthen, 2017). Pola asuh orang tua menjadi cerminan bentuk komunikasi dua arah orang tua dan anak. Pola asuh positif dari segi kontrol orangtua (64\%), kejelasan komunikasi (61\%) dan tuntutan orang tua menjadi matang (54\%). Siswa memiliki motivasi internal (68\%) dan eksternal positif $(55 \%)$ dalam pembelajaran (Harianti \& Amin, 2016).

Keseringan berada dirumah menjadikan antusias belajar anak semakin berkurang. Kecenderungan belajar dengan limit waktu yang telah ditentukan disekolah, tidak lagi ditemui selama dirumah. Persoalan yang ditemui dalam penelitian ini ialah tidak semua orang tua memiliki kepekaan terhadap situasi yang dihadapi sang anak. Pola hidup yang berubah secara tiba -tiba ini, akhinya menurunkan minat belajar anak. Membangun komunikasi secara baik dengan anak, serta 
memberikan motivasi agar semangat belajar terus selalu ada, menjadi poin penting selama masa pandemic ini. Dari hasil penelitian ini, komunikasi sebagian orang tua dalam memotivasi anak nampak sangat jarang, hal ini dikarenakan para orang tua pun ternyata memiliki keresahan dan kebingungan ketika sang anak meminta untuk selalu didampingi saat belajar. Hal ini karena kurangnya pengetahuan lebih terkait materi sekolah, kurangnya penguasaan fitur perangkat pembelajaran online dan juga karena tidak semua orang tua memiliki dorongan untuk memotivasi setiap proses belajar anak.

\section{4 | SIMPULAN DAN SARAN}

Dari hasil ulasan penelitian melalui diperoleh kesimpulan bahwa kesenjangan komunikasi orang tua dan anak selama pembelajaran online dimasa pandemic Covid - 19 terjadi karena ketidaksiapan sebagian orang tua yang dihadapkan pada tanggung jawab ekstra sebagai "guru" pengganti selama anak belajar dari rumah. Kekhawatiran Sebagian orang tua dilatar belakangi oleh beberapa aspek, yakni; ketidaksipaketiadaan waktu, tingkat pengetahuan dan pendidikan orang tua, minimnya pemahaman tentang fitur pembelajaran online anak menjadi faktor terciptanya kesenjangan komunikasi yang dibangun orang tua dan anak. Pola asuh orang tua menjadi cerminan bentuk komunikasi dua arah orang tua dan anak. Pola asuh positif dari segi kontrol orangtua (64\%), kejelasan komunikasi $(61 \%)$ dan tuntutan orang tua menjadi matang $(54 \%)$. Siswa memiliki motivasi internal $(68 \%)$ dan eksternal positif (55\%) dalam pembelajaran. Dari kesimpulan diatas, peneliti juga memberikan beberapa saran praktis kepada para orang tua bahwa komunikasi menjadi bagian vital dalam pengasuhan dan perkembangan mental anak. Komunikasi dua arah menjadi solusi model komunikasi keluarga dalam rangka membuat komunikasi menjadi lebih efektif. Pendidikan yang terbaik berasal dari keluarga, oleh karenanya peran orang tua menjadi peran yang dominan dalam pola asuh keluarga sehingga anak tidak lepas kendali.

\section{UCAPAN TERIMA KASIH}

Ucapan terima kasih penulis sampaikan kepada semua pihak yang telah membantu kelancaran penelitian sampai pada penulisan naskah artikel ilmiah ini; kepada narasumber, pihak pemerintah daerah.

\section{REFERENSI}

Anhusadar, L. (2020). Persepsi mahasiswa PIAUD terhadap kuliah online di masa pandemi Covid 19. KINDERGARTEN: Journal of Islamic Early Childhood Education, 3(1), 44-58. https://doi.org/http://dx.doi.org/10.24014/kjiece.v3i1.9609

Astini, N. K. S. (2020). Pemanfaatan teknologi informasi dalam pembelajaran tingkat sekolah dasar pada masa pandemi covid-19. Lampuhyang, 11(2), 13-25. https://doi.org/https://doi.org/10.47730/jurnallampuhyang.v11i2.194

Bhamani, S., Makhdoom, A. Z., Bharuchi, V., Ali, N., Kaleem, S., \& Ahmed, D. (2020). Home learning in times of COVID: Experiences of parents. Journal of Education and Educational Development, 7(1), 9-26. https://doi.org/http://dx.doi.org/10.22555/joeed.v7i1.3260

Cahyani, A., Listiana, I. D., \& Larasati, S. P. D. (2020). Motivasi Belajar Siswa SMA pada Pembelajaran Daring di Masa Pandemi Covid-19. IQ (IImu Al-Qur'an): Jurnal Pendidikan Islam, 3(01), 123-140. 
Dzaljad, R. G. (2020). Transformasi Sosial dalam Proses Pendidikan di Masa Pandemi Covid-19. MAARIF, 15(2), 305-324.

Fahmi, M. H. (2020). KOMUNIKASI SYNCHRONOUS DAN ASYNCHRONOUS DALAM ELEARNING PADA MASA PANDEMIC COVID-19. Jurnal Nomosleca, 6(2), 146-158.

Fauzie, S. \&. (2017). Penggunaan Kata “Jancuk" Sebagai Ekspresi Budaya dalam Perilaku Komunikasi Arek di Kampung Kota Surabaya. Jurnal Psikologi Teori Dan Terapan, Vol 7. https://doi.org/http://dx.doi.org/10.26740/jptt.v7n2.p88-102

Fauzy, A., \& Nurfauziah, P. (2021). Kesulitan Pembelajaran Daring Matematika Pada Masa Pandemi COVID-19 di SMP Muslimin Cililin. Jurnal Cendekia: Jurnal Pendidikan Matematika, 5(1), 551-561. https://doi.org/https://doi.org/10.31004/cendekia.v5i1.514

Garbe, A., Ogurlu, U., Logan, N., \& Cook, P. (2020). COVID-19 and remote learning: Experiences of parents with children during the pandemic. American Journal of Qualitative Research, 4(3), 45-65. https://doi.org/https://doi.org/10.29333/ajqr/8471

Garbe, Lisa, Richard Rau, and T. T. (2020). "Influence of perceived threat of Covid-19 and HEXACO personality traits on toilet paper stockpiling." Plos One, 15(6), e0234232.

Harianti, R., \& Amin, S. (2016). Pola asuh orangtua dan lingkungan pembelajaran terhadap motivasi belajar siswa. Curricula: Journal of Teaching and Learning, 1(2).

Irma, C., Nisa, K., \& Sururiyah, S. (2019). Keterlibatan Orang Tua dalam Pendidikan Anak Usia Dini Ddi TK Masyitoh Purworejo. Jurnal Obsesi : Jurnal Pendidikan Anak Usia Dini, 3(2). https://doi.org/https://doi.org/10.31004/obsesi.v31i.152.

Jauhari, M. N., Mambela, S., \& Zakiah, Z. (2020). Dampak Pandemi Covid-19 Terhapad Pelaksanaan Pembelajaran Penjas Adaptif Di Sekolah Luar Biasa. STAND: Journal Sports Teaching and Development, 1(1), 63-70.

Kartini, K. (1996). Pengantar Metodologi Riset Sosial. Mandar Maju.

Kurniati, E., Alfaeni, D. K. N., \& Andriani, F. (2020). Analisis Peran Orang Tua dalam Mendampingi Anak di Masa Pandemi Covid-19. Jurnal Obsesi: Jurnal Pendidikan Anak Usia Dini, 5(1), 241256.

Lestari, K., Harun, H., \& Fauziah, P. (2021). Strategi Taman Kanak-Kanak dalam Mengoptimalkan Pembelajaran Masa Pandemi di Kecamatan Nanga Pinoh. Jurnal Obsesi: Jurnal Pendidikan Anak Usia Dini, 5(2), 1951-1959. https://doi.org/: 10.31004/obsesi.v5i2.1014

Liliweri, A. (2017). Komunikasi antar personal. Prenada Media.

Loviana, S., \& Baskara, W. N. (2020). Dampak pandemi covid-19 pada kesiapan pembelajaran tadris matematika IAIN Metro Lampung. Epsilon: Jurnal Pendidikan Matematika, 2(1), 61-70.

Martens, M., Ammar, A., Riutta, A., Waagmeester, A., Slenter, D. N., Hanspers, \& Kutmon, M. (2021). WikiPathways: connecting communities. Nucleic Acids Research, 49(1), 613-621. https://doi.org/https://doi.org/10.1093/nar/gkaa1024

Megawanti, P. (2020). Persepsi Peserta Didik Terhadap PJJ pada Masa Pandemi Covid 19. Faktor: Jurnal Ilmiah Kependidikan, 7(2), 75-82.

Onyema, E. M., Eucheria, N. C., Obafemi, F. A., Sen, S., Atonye, F. G., Sharma, A., \& Alsayed, A. O. (2020). Impact of Coronavirus pandemic on education. Journal of Education and Practice, 11(13), 108-121. https://doi.org/10.7176/JEP/11-13-12

Parczewska, T. (2021). Difficult situations and ways of coping with them in the experiences of parents homeschooling their children during the COVID-19 pandemic in Poland. Education, 49(7), 889-900. https://doi.org/https://doi.org/10.1080/03004279.2020.1812689

Pujilestari, Y. (2020). Dampak positif pembelajaran online dalam sistem pendidikan Indonesia pasca pandemi covid-19. Adalah, 4(1), 13-23. https://doi.org/10.15408/adalah.v4i1.15394

Putria, H., Maula, L. H., \& Uswatun, D. A. (2020). Analisis proses pembelajaran dalam jaringan (daring) masa pandemi covid-19 pada guru sekolah dasar. Jurnal Basicedu, 4(4), 861-870. 
https://doi.org/https://doi.org/10.31004/basicedu.v4i4.460

Rochman, B., Indahwati, N., \& Priambodo, A. (2020). Identifikasi Keterlaksanaan Pembelajaran PJOK Tingkat SMP Di Masa Pandemi Covid 19 Se-Kabupaten Sidoarjo. Jurnal IImiah Mandala Education, 6(1).

Samudera, W. (2020). Dampak Pandemi Covid-19 Dalam Bidang Pendidikan Di Kota Mataram. Indonesian Journal of Teacher Education, 1(3), 154-158.

Setiyaningsih, L. A., \& Jatmikowati, S. H. (2019). Media Baru Dalam Komodifikasi Waktu Luang Ibu Rumah Tangga. ETTISAL: Journal of Communication, 4(1), 23-32.

Setiyaningsih, L. A., Fahmi, M. H., \& Molyo, P. D. (2021). Selective Exposure Media Sosial Pada Ibu dan Perilaku Anti Sosial Anak. Jurnal Komunikasi Nusantara, 3(1), 1-11. https://doi.org/10.33366/jkn.v3i1.65

Setiyaningsih, L. A., Fahmi, M. H., \& Sawidodo, F. (2020). Media Referensi Berbasis Teknologi Facebook Bagi Wartawan Dalam Menyusun Berita. Jurnal Spektrum Komunikasi, 8(2), 159176. https://doi.org/10.37826/spektrum.v8i2.101

Sudrajat, C. J., Agustin, M., Kurniawati, L., \& Karsa, D. (2020). Strategi Kepala TK dalam meningkatkan mutu pendidikan pada masa pandemi Covid 19. Jurnal Obsesi: Jurnal Pendidikan Anak Usia Dini, 5(1), 508-520. https://doi.org/10.31004/obsesi.v5i1.582

Sugiyono. (2017). Metode Penelitian Kuantitatif, Kualitatif, dan R\&D. CV. Alfabeta.

Suhendro, E. (2020). Strategi Pembelajaran Pendidikan Anak Usia Dini di Masa Pandemi Covid19. Golden Age: Jurnal Ilmiah Tumbuh Kembang Anak Usia Dini, 5(3), 133-140. https://doi.org/https://doi.org/10.14421/jga.2020.53-05

Trevarthen, C. (2017). T. function of emotions in early infant communication and development. I. N. perspectives in early communicative development (pp. 48-81). R. (2017). The function of emotions in early infant communication and development. In New perspectives in early communicative development. Routladge.

Triono, M. A., \& Setiyaningsih, L. A. (2017). Desain Disonansi Kognitif Sebagai Faktor Anteseden Untuk Penguatan Kualitas Informasi Pada Website. Seminar Nasional Sistem Informasi, 1(1), 71-79. http://eprints.unmer.ac.id

Uzun, H., Karaca, N. H., \& Metin, Ş. (2021). Assesment of parent-child relationship in Covid-19 pandemic. Children and Youth Services Review, 120, 105748.

Wardani, A., \& Ayriza, Y. (2020). Analisis kendala orang tua dalam mendampingi anak belajar di rumah pada masa pandemi Covid-19. Jurnal Obsesi: Jurnal Pendidikan Anak Usia Dini, 5(1), 772-782. https://doi.org/: 10.31004/obsesi.v5i1.705 